\title{
Skor prediksi sindrom disfungsi multi-organ pada pasien multitrauma
}

\author{
${ }^{1}$ Leo Rendy \\ ${ }^{1}$ Heber B. Sapan \\ ${ }^{1}$ Laurens T. B. Kalesaran \\ ${ }^{2}$ Julius H. Lolombulan
}

\author{
${ }^{1}$ Bagian Ilmu Bedah Fakultas Kedokteran Universitas Sam Ratulangi Manado \\ RSUP Prof. Dr. R. D. Kandou Manado \\ ${ }^{2}$ Bagian Statistik Unima Tondano \\ Email: rendy_mercury@yahoo.com
}

\begin{abstract}
Multiple organ dysfunction syndrome (MODS) in patients with major trauma remains to be frequent and devastating complication during clinical course in emergency department and intensive care unit (ICU). The ability to easily and accurately identify patients at risk for MODS postinjury especially in multitrauma cases would be very valuable. This study aimed to construct an instrument for prediction of the development of MODS in adult multitrauma patients using clinical and laboratory data available in the first day at prahospital and emergency department (hospital) setting. This was a prospective study. Samples were adult multitrauma patients with Injury Severity Score (ISS) $\geq 16$, aged 16-65 years old, admitted to 4 academic Level-I trauma center from September 2014 to September 2015. Sequential organ failure assessment (SOFA) score was used to determine MODS during hospitalization. A risk score created from the final regression model consisted of significant variables as MODS predictor. The results showed that there were 98 multitrauma patients as samples. The mean age was 35.2 years old; mostly male (85.71\%); the mean of ISS was 23.6; mostly $(76.53 \%)$ were caused by blunt injury mechanism. MODS was encountered in 43 patients $(43.87 \%)$. The prediction risk score consists of Revised Trauma Score (RTS) $(<7.25)$ and serum lactate level $\geq 2 \mathrm{mmol} / \mathrm{L}$. This study also verified several independent risk factors for post multitrauma MODS, such as ISS >25, presence of SIRS, shock grade 2 or more, and white blood cell count $>12,000 / \mathrm{mm}^{3}$. Conclusion: We derived a novel, simple, and applicable instrument to predict MODS in adult following multitrauma. The use of this scoring system may allow early identification of multitrauma patients who are at risk for MODS and result in more aggressive targeted resuscitation and better referral allocation based on regional trauma system.
\end{abstract}

Keywords: MODS, multitrauma, emergency department, MODS prediction score

\begin{abstract}
Abstrak: Sindrom disfungsi multi-organ (MODS) merupakan komplikasi buruk yang sering terjadi sepanjang perjalanan klinis pasien trauma mayor di Unit Gawat Darurat (UGD) maupun di ruang perawatan intensif. Suatu nilai patokan yang dapat memprediksi MODS pascatrauma secara akurat sejak dini tentunya sangat berharga bagi tatalaksana pasien terutama pada kasus multitrauma. Penelitian ini bertujuan untuk membuat suatu instrumen yang dapat memrediksi perkembangan MODS pada pasien dewasa multitrauma dengan menggunakan data klinis dan laboratorium yang tersedia pada 24 jam pertama pasca trauma pada seting fase prahospital maupun di fase hospital sejak di UGD. Jenis penelitian ini prospektif, mengumpulkan pasien multitrauma dengan Injury Severity Score (ISS) $\geq 16$, rentang usia 16-65 tahun, di 4 pusat trauma level-1 rumah sakit pendidikan selama 1 tahun (September 2014-2015). Dilakukan pencatatan data klinis dan laboratorium sesuai perkembangan pasien. Skor sequential organ failure assessment (SOFA) digunakan untuk menentukan adanya MODS selama perawatan. Skor prediksi dibuat dengan membangun
\end{abstract}


model regresi logistik yang signifikan untuk memrediksi terjadinya MODS pasca multitrauma. Hasil penelitian mendapatkan 98 sampel multitrauma yang memenuhi kriteria inklusi dengan rerata usia 35,2 tahun, sebagian besar laki-laki $(85,71 \%)$ dengan rerata ISS 23,6, dan disebabkan oleh trauma tumpul (76,53\%). MODS terjadi pada 43 pasien (43,87\%). Skor prediksi terdiri dari RTS dengan (cut off point 7,25) dan kadar laktat serum (cut off point $3,44 \mathrm{mmol} / \mathrm{mL}$ ). Penelitian ini juga memverifikasi beberapa faktor risiko individual terjadinya MODS pasca multitrauma yaitu ISS $>25$, adanya SIRS, syok derajat 2 atau lebih, dan leukositosis >12.000. Simpulan: Kami melaporkan instrumen baru yang praktis untuk memrediksi MODS pada pasien multitrauma dewasa. Skor ini memungkinkan identifikasi dini pasien trauma yang berisiko akan mengalami MODS sehingga dapat menjadi tanda alarm dilakukannya resusitasi yang lebih agresif dan tepat serta alokasi rujukan pasien yang lebih efisien berdasarkan sistem trauma regional.

Kata kunci: MODS, multitrauma, UGD, skor prediksi MODS

Multitrauma didefinisikan sebagai cedera yang mengenai setidaknya dua regio tubuh dengan derajat berat trauma yang diukur dengan Injury Severity Score (ISS) $<16$. Trauma mayor ini hampir selalu disertai oleh adanya systemic inflammation response syndrome (SIRS) setidaknya selama 1 hari pada 72 jam pertama pasca trauma. ${ }^{1,2}$ Trauma mayor menimbulkan gangguan fisiologik dan kondisi hiperinflamasi yang dapat mengarah ke disfungsi satu atau lebih sistem organ (MODS) yang dapat berakhir dengan kegagalan multi-organ (multiorgan failure, MOF). ${ }^{3}$

Insidens MODS-MOF pasca trauma sekitar 29\%. ${ }^{4}$ Angka mortalitas pasien trauma mayor dengan kegagalan dua sistem organ mencapai $67 \%$, dan mendekati $100 \%$ bila terjadi kegagalan lebih dari 3 sistem organ. $^{5}$ Sebelumnya telah diciptakan beberapa sistem skor trauma untuk memilah pasien berdasarkan risiko mortalitasnya. Paradigma ini sangat berharga bagi proses triage, resusitasi yang lebih baik, dan manajemen trauma secara keseluruhan. Beratnya trauma dengan ISS $\geq 25$, adanya SIRS, dan sepsis merupakan komponen patofisiologik terjadinya MODS-MOF pasca trauma. ${ }^{6,7}$ Beberapa penelitian terdahulu telah menemukan faktor-faktor yang berkorelasi dengan terjadinya MODS-MOF pasca trauma, seperti usia tua, skor trauma tinggi (first hit), adanya syok, defisit basa $<8 \mathrm{mEq} / \mathrm{L}$, hiperlaktatemia $>2,5 \mathrm{mmol} / \mathrm{L}$ pada 24 jam pertama pasca trauma, transfusi darah masif lebih dari 6 kantung sel darah merah, meningkatnya kadar interleukin-6, dan dilakukannya kontrol jalan napas emergensi definitif selama fase prahospital maupun saat resusitasi di unit gawat darurat. $^{8,9}$ Penelitian-penelitian tersebut berusaha memvalidasi faktor risiko timbulnya MODS pasca trauma menggunakan variabel penilaian yang dilakukan saat fase prahospital maupun di Unit Gawat Darurat (UGD). Identifikasi dini yang cepat akan sangat membantu proses rujukan pasien trauma dan resusitasi agresif yang lebih tepat bisa dimulai lebih dini sebelum kaskade sistemik pasca trauma terlanjur berlangsung dan memburuk hingga titik nadirnya berupa MOF yang tentu saja memiliki angka mortalitas tinggi dan menghabiskan sumber daya dan biaya kesehatan yang sangat tinggi.

\section{METODE PENELITIAN}

Sampel penelitian berasal dari 4 pusat trauma level-1 di Rumah Sakit Prof. Dr. R. D. Kandou Manado, Rumah Sakit Dr. Kariadi Semarang, Rumah Sakit Sanglah Bali, dan Rumah Sakit Universitas Hasanuddin Makassar. Penelitian ini merupakan studi cohort prospektif selama 1 tahun dengan kriteria inklusi sebagai berikut: pasien multitrauma dengan ISS $\geq 16$, berusia 16-65 tahun, tidak menderita penyakit kronik lain, serta belum pernah mengalami trauma mayor dan pembedahan sebelumnya. Penelitian ini 
telah mendapatkan ethical clearance dengan nomor registrasi UH15050350 dari Badan Koordinasi Pendidikan dan komite etik di tiap rumah sakit yang terlibat.

Data demografik penelitian mencakup usia, jenis kelamin, waktu transfer prahospital, tanda-tanda vital saat masuk rumah sakit, ada-tidaknya jalan napas emergensi definitif selama transfer pasien atau saat di UGD. Beratnya cedera di tiap regio tubuh dinilai derajatnya dengan Abbreviated Injury Scale (AIS) untuk membangun nilai ISS. Diagnosis final dan intervensi bedah yang dilakukan juga dicatat. Data laboratorium yang dicatat ialah hasil pemeriksaan darah rutin, kadar laktat serum saat masuk rumah sakit, tes fungsi ginjal dan hati, analisis gas darah, serta pemeriksaan tambahan lainnya sesuai perjalanan klinis pasien.

Keluaran penelitian ini yaitu adanya MODS-MOF yang dinilai berdasarkan sistem skor Sequential Organ Faiure Assessment (SOFA). ${ }^{10}$ SOFA menilai disfungsi hingga kegagalan enam sistem organ yaitu penilaian rasio $\mathrm{PaO}_{2} / \mathrm{FIO}_{2}$ (sistem respirasi), jumah trombosit (sistem koagulasi-hematologi), nilai Glasgow Coma Scale (sistem saraf pusat), mean arterial pressure dan penggunaan inotropik (sistem kardiovaskular), keluaran urin dan kadar kreatinin (sistem renal), dan bilirubin total (sistem digestif-hepar). Adanya MODS didefinisikan sebagai skor SOFA $>1$ pada lebih dari satu sistem organ, dan dikatakan MOF bila skor SOFA $\geq 3$ pada lebih dari satu sistem organ. Keluaran lain yang juga dicatat dalam cohort ini ialah masa rawat di ICU, total masa rawat inap di rumah sakit, dan angka mortalitas.

\section{HASIL PENELITIAN}

Selama satu tahun penelitian didapatkan 98 pasien multitrauma yang memenuhi kriteria inklusi dan menjadi sampel penelitian. Rerata usia pasien 35,2 tahun, sebagian besar lelaki $(85,71 \%, 84$ vs 14), sebagian besar trauma disebabkan oleh kecelakaan lalu lintas $(73,47 \%)$ dengan mekanisme truma tumpul $(76,53 \%)$ (Tabel 1). Usia dan jenis kelamin bukan merupakan prediktor yang signifikan untuk terjadinya MODS sehingga dieksklusi dari model prediksi.

Rerata derajat beratnya trauma yang dinilai dengan ISS 23,59 dan dengan RTS 7,345 .

Tabel 1. Data demografik dan karakteristik sampel penelitian

\begin{tabular}{ll}
\hline \multicolumn{1}{c}{ Data } & Hasil \\
\hline $\begin{array}{l}\text { Total, N } \\
\text { Usia }\end{array}$ & 38 \\
Jenis kelamin; laki-laki:perempuan & $84(85,71 \%): 14(14,28 \%)$ \\
Kausa; & $72(73,47 \%)$ \\
• Kecelakaan lalu lintas & $12(12,24 \%)$ \\
- Kekerasan kriminal & $7(8,11 \%)$ \\
- Jatuh dari ketinggian & $2(1,35 \%)$ \\
- Kekerasan akibat hewan & $2(1,35 \%)$ \\
- Termal/listrik/kimiawi & \\
Mekanisme; & $75(76,53 \%)$ \\
- tumpul & $11(11,22 \%)$ \\
- penetrans & $12(12,24 \%)$ \\
• kombinasi & $6,33 *$ \\
Durasi prahospital (jam) & $54(55,10 \%)$ \\
• dirujuk dari instansi kesehatan lain & $44(44,90 \%)$ \\
• langsung ke pusat trauma peneliti &
\end{tabular}


Kebanyakan sampel mengalami SIRS $(88,89 \%)$, dengan leukositosis (mean $19,455 \mathrm{sel} / \mu \mathrm{L}$ ), kadar laktat tinggi (mean $3,14 \mathrm{mmol} / \mathrm{L}$ ), jumlah trombosit normal $(229,000 \mathrm{sel} / \mu \mathrm{L})$, dan 12 pasien menjalani pemasangan jalan napas emergensi definitive (12,2\%). Dari 98 sampel, 43 sampel mengalami syok dengan derajat syok yang berbeda-beda (mean derajat 2,05). Terdapat lima variabel yang signifikan sebagai prediktor individual terjadinya MODS menurut analisis univariat (Tabel 2).

Dari seluruh sampel multitrauma, 43 mengalami MODS $(43,87 \%)$ dan dari pasien yang mengalami MODS, 12 pasien memburuk menjadi MOF (12,24\%). Jumlah kematian saat perawatan di rumah sakit sebanyak 13 (11 MOF, 2 MODS) $(13,26 \%)$.
Tabel 3 mengenai keluaran (outcome) penelitian ini dan Gambar 1 mengenai distribusi MODS. Rerata lama rawat inap seluruh sampel yaitu 11,06 hari.

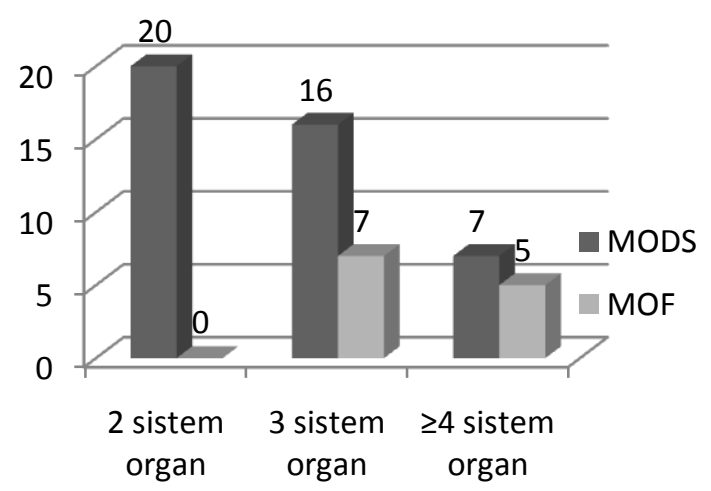

Gambar 1. Distribusi sistem organ yang terkena MODS-MOF pascamultitrauma

Tabel 2. Variabel individual prediktor MODS dan signifikansinya

\begin{tabular}{lccccc}
\hline \multicolumn{1}{c}{ Variabel } & Mean & Sig. & Cut off point & Sensitivitas & Spesifisitas \\
\hline $\begin{array}{l}\text { ISS } \\
\text { Jalan napas emergensi }\end{array}$ & 23,59 & $<0,0001^{*}$ & 25,8 & $51,2 \%$ & $80 \%$ \\
definitif & & 0,99 & - & - & - \\
RTS & $7 ., 354$ & $<0,001^{*}$ & 7,25 & $65,1 \%$ & $78,2 \%$ \\
SIRS & 88 & $0,02^{*}$ & & & \\
& $(88,89 \%)$ & & & & \\
Syok & 2,05 & $<0,001^{*}$ & 1,86 & $74,4 \%$ & $70,9 \%$ \\
Hemoglobin & 12,29 & 0,078 & - & - & \\
Leukosit $(\mathrm{sel} / \mu \mathrm{L})$ & 19,455 & $0,048^{*}$ & 11.980 & $90,7 \%$ & $25,5 \%$ \\
Trombosit $(\mathrm{sel} / \mu \mathrm{L})$ & 229.000 & 0,128 & - & - & - \\
Laktat $(\mathrm{mmol} / \mathrm{L})$ & 3,14 & $<0,001^{*}$ & 3,44 & $48,8 \%$ & $85,5 \%$ \\
\hline
\end{tabular}

*signifikan, $<0,05$

Tabel 3. Keluaran sampel penelitian

\begin{tabular}{|c|c|c|}
\hline Data & $\mathbf{N}$ & Persentase \\
\hline MODS & 43 & $43,87 \% *$ \\
\hline - 2 sistem organ & - 20 & - $46,51 \%{ }^{\#}$ \\
\hline - 3 sistem organ & - 16 & - $37,21 \%{ }^{\#}$ \\
\hline - $\geq 4$ sistem organ & - 7 & - $16,28 \%{ }^{\#}$ \\
\hline MOF & $\begin{array}{l}12 \text { dari } 43 \text { MODS berkembang } \\
\text { menjadi MOF }\end{array}$ & $12,24 \% *$ dan $27,91 \%{ }^{\#}$ \\
\hline Meninggal selama perawatan & 13 (11 dari MOF, 2 dari MODS) & $13,26 \% *$ dan $30,23 \% \#$ \\
\hline Lama rawat inap (hari) & $11,06 *$ dan $12,28^{\#}$ & \\
\hline Perawatan di ICU (hari) & $1,59 *$ dan $2,95^{\#}$ & \\
\hline
\end{tabular}

*dari seluruh sampel multitrauma; \# dari seluruh sampel yang mengalami MODS 
92 Jurnal Biomedik (JBM), Volume 8, Nomor 2, Juli 2016, hlm. 88-95

Tabel 4. Distribusi MODS pasca multitrauma dan sistem organ yang terlibat

\begin{tabular}{|c|c|c|c|c|c|c|c|}
\hline MODS & Respirasi & $\begin{array}{l}\text { Kardio- } \\
\text { vaskular }\end{array}$ & Renal & $\begin{array}{l}\text { Hemato- } \\
\text { logi }\end{array}$ & Neurologi & Hati & Total \\
\hline 2 sistem organ & 8 & 6 & 7 & 4 & 6 & 0 & $\begin{array}{c}31 \\
(25,6 \%)\end{array}$ \\
\hline 3 sistem organ & 13 & 14 & 7 & 11 & 11 & 1 & $\begin{array}{c}57 \\
(47,1 \%)\end{array}$ \\
\hline $\begin{array}{l}\geq 4 \text { sistem } \\
\text { organ }\end{array}$ & 7 & 5 & 7 & 6 & 6 & 2 & $\begin{array}{c}33 \\
(27,3 \%)\end{array}$ \\
\hline Total & $\begin{array}{c}28 \\
(23,1 \%)\end{array}$ & $\begin{array}{c}25 \\
(20,6 \%)\end{array}$ & $\begin{array}{c}21 \\
(17,4 \%)\end{array}$ & $\begin{array}{c}21 \\
(17,4 \%)\end{array}$ & $\begin{array}{c}23 \\
(19 \%)\end{array}$ & $\begin{array}{c}3 \\
(2,5 \%)\end{array}$ & $\begin{array}{c}121 \\
(100 \%)\end{array}$ \\
\hline
\end{tabular}

\section{Model skor prediksi MODS pasca multitrauma}

Setelah dilakukan analisis univariat untuk tiap faktor risiko independen, seluruh variabel dianalisis sebagai satu kesatuan menggunakan analisis regresi logistik multivariat. Dengan model yang terdiri dari 9 variabel, analisis statistik menunjukkan hasil yang tidak signifikan. Langkah berikutnya ialah membangun model prediksi yang disusun dari tiap variabel satu-persatu tanpa menghilangkan signifikansi model. Komposisi final terbaik model prediksi terdiri dari RTS dan kadar laktat dengan signifikansi $P=0,002$. Formula/persamaan prediksi ini ialah sebagai berikut:

$\mathrm{P}=\frac{1}{\left[1+\mathrm{e}^{-[10,33+0,52(\text { kadar laktat) }-1,65 \text { (nilai RTS) }]}\right.}$

$\mathrm{P}=$ peluang terjadinya MODS, $0 \leq \mathrm{P} \leq 1$

$\mathrm{e}=2,71 ; 10,33$ adalah konstanta model regresi terbaik; 0,52 adalah koefisien regresi laktat; 1,65 adalah koefisien regresi RTS

Sebagai contoh, pasien multitrauma yang mengalami komosio serebri, trauma tumpul abdomen, tension pneumothorax, dan fraktur zygoma, masuk ke UGD dengan tekanan darah sistolik $80 \mathrm{mmHg}$, frekuensi pernapasan $30 \mathrm{kali} / \mathrm{menit}$, GCS 14, RTS pasien 6,817, dan kadar laktat serum 4,5 mmol/L.

Skor prediksi MODS pascamultitrauma = $\frac{1}{1+\mathrm{e}^{-(10,3+0,52.4 \cdot 5-1,65 \cdot 6,817)}}=0,92(92 \%)$.

Pasien ini $92 \%$ berpeluang akan mengalami MODS pasca trauma.

\section{BAHASAN}

Kerusakan anatomik diwakili oleh nilai ISS. Derajat beratnya cedera anatomik memiliki kekuatan prediksi untuk memrediksi terjadinya MODS. ${ }^{11}$ Penelitian ini dilakukan pada pasien multitrauma dengan ISS $\geq 16$ dengan alasan bahwa pasien trauma mayor memiliki kemungkinan lebih besar berkembang menjadi MODS-MOF dibandingkan trauma minor. Kerusakan anatomik (sel dan jaringan) akan menimbulkan reaksi fisiologik berupa peningkatan frekuensi jantung, pernapasan, penurunan tingkat kesadaran, syok, aktifnya jalur metabolisme alternatif (dengan hasil tingginya kadar laktat), menghasilkan mediator inflamasi, timbul SIRS yang sangat mungkin memburuk menjadi MODS dengan MOF, dan kematian sebagai hasil akhir yang paling buruk.

Parameter fisiologik yang memiliki korelasi signifikan dengan MODS ialah RTS, syok, dan SIRS. Rendahnya nilai RTS, beratnya derajat syok, dan adanya SIRS saat pasien masuk rumah sakit atau di fase prahospital menunjukkan kekacauan fisiologik akibat trauma dan resusitasi yang tidak adekuat. Resusitasi yang tidak adekuat membuat kaskade hiperinflamasi SIRS-MODS-MOF berjalan, dan rangkaian kerja ini harus dihentikan dengan prinsip advanced trauma life support (ATLS) dan definitive surgical trauma care (DSTC). Parameter lain yang menunjukkan perburukan fungsi tubuh yang signifikan yaitu tingginya kadar laktat $(>3,44$ $\mathrm{mmol} / \mathrm{L})$ dan leukositosis (>11,980 
12,000/ $\mu \mathrm{L})$. Jumlah leukosit dalam sirkulasi sistemik sebagai respons inflamasi akan meningkat sebanding dengan beratnya trauma. Hiperlaktatemia terjadi akibat aktifvasi jalur metabolism anaerob karena jalur metabolism aerob (utama) tidak dapat berjalan pada keadaan seperti syok, iskemia, dan hipoksia, apalagi pada pasien yang membutuhkan pemasang-an jalan napas definitif emergensi.

Seluruh variabel ini memiliki interaksi satu dengan lainnya. Sebagai contoh, definisi SIRS dan syok memiliki area tumpang tindih untuk komponen definisinya dalam hal tanda-tanda vital. Pasien yang menglami syok hemoragik derajat berat akan memiliki nilai RTS yang rendah karena tekanan darahnya menurun, kesadarannya menurun, dan laju napasnya meningkat. Leukositosis merupakan salah satu komponen definisi dari SIRS. Pasien trauma yang mengalami syok hipovolemik akibat perdarahan masif akan mengalamai trombositopenia, anemia, hipotensi, dan menurun kesadarannya (nilai RTS rendah). Pasien yang mengalami cedera berat di berbagai regio tubuhnya (nilai ISS tinggi) dapat mengalami syok disertai perdarahan yang terus berlangsung, yang akan diikuti oleh turunnya kadar hemoglobin, takikardia, peningkatan frekuensi pernapasan seiring terjadinya SIRS. Pasien trauma yang memerlukan pemasangan jalan napas emergensi pasti berada dalam kondisi hipoksia, dan bila pasien tersebut juga mengalami syok hemoragik, jalur metabolism anaerob akan diaktifkan dengan hasil akhirnya meningkatnya kadar laktat. ${ }^{12}$ Analisis regresi logistik multivariat secara kmembantu menilai interaksi antar variabel ini dan hasil akhirnya ada dua variabel yang signifikan secara bersama sebagai model prediksi MODS pasca multitrauma

\section{Data keluaran}

MODS terjadi pada $43,87 \%$ sampel multitrauma dan sepertiga akhirnya mengalami perburukan menjadi MOF pada tiga sistem organ atau lebih dengan angka mortalitas $91,67 \%$. Sistem organ yang terlibat pada MODS pasca multitrauma penelitian ini dapat dilihat pada Tabel 4 . MODS merupakan tahap terakhir sebelum MOF. MODS dan MOF memiliki angka mortalitas yang tinggi dan prinsip tatalaksana MODS ialah terapi suportif organ di unit rawat intensif yang tentu saja menghabiskan biaya kesehatan yang besar dengan angka mortalitas yang juga tinggi. Dibandingkan usaha kuratif, strategi prevensi dan deteksi dini tentu akan lebih berharga untuk mengatasi MODS. ${ }^{13}$ Strategi damaged control dan resusitasi terarah sedini mungkin diharapkan dapat menurunkan morbiditas dan mortalitas akibat MODS-MOF pasca multitrauma, dan hal ini hanya dapat dilakukan bila pasien yang berisiko tinggi akan terkena MODS dapat dikenali atau dideteksi sedini mungkin dengan suatu alat prediktor.

\section{Skor prediksi MODS pasca multitrauma}

Skor prediksi ini didesain sebagai instrumen yang digunakan pada triage untuk menstratifikasi pasien yang berisiko mengalami MODS pascatrauma (skor prediksi $>0,5 / 50 \%$ berpeluang mengalami MODS) akan ditransfer ke pusat trauma level-I/Major Trauma Center (MTC) yang dilengkapi oleh ahli bedah trauma yang bersiaga 24 jam disertai fasilitas surgical intensive care unit (SICU) sehingga intervensi yang tepat dan dilakukan sedini mungkin dapat memutuskan mata rantai perburukan SIRS-MODS-MOF-meninggal sejak awal. Pasien yang diprediksi lebih tidak mungkin akan mengalami MODS pasca trauma (skor $<0,5$ ) akan dirujuk ke pusat trauma level II-III/Trauma Unit (TU). Dengan signifikansi ISS $\geq 26$, SIRS, syok hipovolemik derajat 2 atau lebih, leukositosis $\geq 12,000$ sebagai predikotr univariat MODS, dan laktat-RTS sebagai satu model prediktor, kami mengusulkan algoritma triage untuk pasien multitrauma yang merupakan modifikasi algoritma triage yang disusun oleh Jansen et al. ${ }^{14}$ (2015), member dari the Major Trauma Oversight Group (MTOG) for the Scottish 
National Trauma System Implementation Group.

Dari penelusuran pubmed, terdapat satu penelitian senada dengan penelitian ini yaitu penelitian mengenai kegagalan organ pasca trauma Denver Emergency Departement Trauma Organ Failure (TOF) score yang dikembangkan oleh Vogel et al (2014). ${ }^{15}$ Vogel et al. membuat suatu skor prediksi kegagalan multi-organ pasca trauma juga menggunakan model regresi logistik dan skor SOFA untuk menentukan ada-tidaknya MOF. TOF score terdiri dari beberapa variabel seperti usia $\geq 65$ tahun, intubasi emergensi, kadar hematokrit, tekanan darah sistolik, blood urea nitrogen $\geq 30 \mathrm{mg} / \mathrm{dL}$, dan leukosit $\geq 20.000 / \mu \mathrm{L}$. Penelitian Vogel ini merupakan penelitian senter tunggal, dengan 4000 partisipan trauma dewasa. Perbedaan penelitian kami dengan penelitian Denver ialah: 1) TOF Denver score merupakan penelitian retrospektif sedangkan penelitian kami merupakan penelitian cohort prospektif; 2) Kriteria inklusinya mencakup seluruh pasien trauma termasuk trauma minor, sedangkan penelitian kami hanya menginklusi pasien trauma mayor yang memiliki kemungkinan lebih besar mengalami MODS sebagai satu tahap sebelum MOF. Menurut opini kami, lebih baik menciptakan suatu alat prediktor yang memrediksi keadaan yang sudah buruk (MODS) sebelum spektrum perburukan penyakit mencapai titik akhir terburuknya yaitu MOF yang tentu saja lebih sulit ditangani.

\section{SIMPULAN}

Kami melaporkan suatu instrumen baru yang aplikatif untuk memrediksi MODS pada pasien multitrauma dewasa. Kegunaan skor prediksi ini yaitu memungkinkan identifikasi ancaman perburukan pasien trauma sejak dini dalam 24 jam pertama pasca trauma. Tanda "alarm" untuk memilah pasien yang berisiko mengalami MODS memungkinkan dilakukannya resusitasi agresif yang terarah disertai alokasi rujukan yang tepat berdasrakan sistem trauma regional.

Skor prediksi MODS pasca multitrauma memiliki manfaat lain sebagai masukan bagi Komisi Trauma Nasional dalam merancang sistem trauma nasional berdasarkan level pusat trauma di seluruh Indonesia.

\section{SARAN}

Diperlukan penelitian lanjutan yang secara prospektif memvalidasi alat prediktor ini pada populasi trauma yang heterogen dalam skala besar dan dilakukan multisenter.

Kami memerlukan persetujuan dari Komisi Trauma Nasional sebelum skor dan usulan algoritma triage pasien multitrauma ini diimplementaikan sebagai panduan praktik klinis oleh komunitas trauma

Saat ini sedang dilakukan proyek kecil untuk membuat kalkulator sederhana berbasis sistem Android® untuk mempermudah perhitungan RTS, ISS, dan skor prediksi MODS pasca multitrauma di lapangan.

\section{DAFTAR PUSTAKA}

1. Mohta M, Dickson RE, McNeill JM. What do we mean by the term polytrauma. Letter to the editor. Injury. 2008;39:962-3.

2. Butcher N, Balogh ZJ. The definition of polytrauma: the need for international consensus. Int. J. Care Injured. 2009; 40S4:12-22

3. Fry DE. Chapter 3: Systemic inflammatory response and multiple organ dysfunction syndrome: biological domino efect. In: Baue AR. Faist E, Fry DE, editors. Multiple Organ Failure: pathophysiology, prevention, and therapy. New York: SpringerVerlag, 2000.

4. Baue AE. Chapter 1: History of MOF and definitions of organ failure. In: Baue AE, Berlot G, Gullo A (editors). Multiple organ failure: pathophysiology, prevention, and therapy. New York: Springer Verlag, 2000.

5. Knaus WA, Draper EA, Wagner DP, 
Zimmerman JE. Prognosis in acute organ-system failure. Ann Surg. 1985; 202: 685-93

6. Cryer HG, Leong K, McArthur DL, Demetriades D, Bongard FS, Fleming AW. Multiple organ failure: by the time you predict it, it's already there. J Trauma. 1999;46:597-604

7. Lausevic Z, Lausevic M, Stankovic JT, Krstic S, Stojimirovic B. Predicting multiple organ failure in patients with severe trauma. Can J Surg. 2008; 51(2):97-102.

8. Ciesla DJ, Moore FA, Moore EE. Chapter 68: Multiple organ failure. In: Feliciano DV, Mattox KL, Moore EE, editors. Trauma (6th ed). New York : McGraw Hill, 2008.

9. Vogel JA, Liao MM, Hopkins E, Seleno N, Byyny RL, Moore EE, et al. Prediction of postinjury multipleorgan failure in the emergency department: development of the Denver emergency department trauma organ failure score. J Trauma Acute Care Surg. 2014;76(1):140-5.

10. Antonelli M, Moreno R, Vincent JL, Sprung CL, Mendoça A, Passariello M. Application of SOFA score to trauma patients: sequential organ failure assessment. Intensive Care Med. 1999; 25:389-94.

11. Tran DD, Cuesta MA, van Leeuwen PAM, Nauta J J P, Wesdorp R I C.
Risk factors for multiple organ failure and death in critically injured patients. Surgery. 1993;114:21-30.

12. Adams ST, Leveson SH. Research methods and reporting: Clinical prediction rules. BMJ. 2012; 344(d8312):1-7.

13. Dewar D, Moore FA, Moore EE, Balogh Z. Postinjury multiple organ failure. Injury, Int. J. Care Injured. 2009;40:912-8.

14. Jansen JO, Morrison JJ, Wang H, Shan He, Lawrenson R, Hutchinson JD, et al. Access to specialist care: optimizing the geographic configuration of trauma system. J1 Trauma Acute Care Surg. 2015; 00(00):1-10.

15. Vogel J, Liao M, Hopkins E, Seleno N, Byyny R, Gravitz C, et al. Derivation of a simple instrument to predict multiple organ failure in adult trauma patients. J Trauma Acute Care Surg. $\quad 2014 ; 76(1): 140-5$. Doi: 10.1097/TA.0b013e3182a99da4.

16. Rotondo MF, Cribari C, Smith RS (eds). Resources for optimal care of the injured patient 2014. Committee on Trauma. American College of Surgeons 2014. [cited 2016 Jan 25]. Available from: http://www.facs.org: Resources for optimal care 2014 v11.pdf: 